Article

\title{
Preparation of $\mathrm{BiPO}_{4} /$ graphene photoelectrode and its photoelectrocatalyitic performance
}

\author{
Zetian He a, Sen Liu a, Yi Zhong a, Daimei Chen a,*, Hao Ding a,\#, Jiao Wang b, Gaoxiang Du a, \\ Guang Yang a, Qiang Hao ${ }^{c}$ \\ a Beijing Key Laboratory of Materials Utilization of Nonmetallic Minerals and Solid Wastes, National Laboratory of Mineral Materials, School of Materials \\ Science and Technology, China University of Geosciences, Beijing 100083, China \\ B Beijing Polytechnic College, Beijing 100042, China \\ c Centre for Technology in Water and Wastewater, School of Civil and Environmental Engineering, University of Technology Sydney, Sydney 2007, \\ Australia
}

\section{A R T I C L E I N F O}

\section{Article history:}

Received 29 September 2019

Accepted 9 October 2019

Published 5 February 2020

\section{Keywords:}

Reduced graphene oxide

$\mathrm{BiPO}_{4}$

Fluorine-doped tin oxide

Electrodeposition

Photoelectrocatalysis

Methyl orange

\begin{abstract}
A B S T R A C T
In this work, a two-step electrodeposition method was employed to prepare $\mathrm{BiPO}_{4}$ nano$\mathrm{rod} /$ reduced graphene oxide/FTO composite electrodes $\left(\mathrm{BiPO}_{4} / \mathrm{rGO} / \mathrm{FTO}\right)$. The $\mathrm{BiPO}_{4} / \mathrm{rGO} / \mathrm{FTO}$ composite electrode showed the higher photoelectrocatalytic (PEC) activity for the removal of methyl orange than pure $\mathrm{BiPO}_{4}$, which was 2.8 times higher than that of $\mathrm{BiPO}_{4} / \mathrm{FTO}$ electrode. The effects of working voltage and $\mathrm{BiPO}_{4}$ deposition time on the degradation efficiency of methyl orange were investigated. The optimum $\mathrm{BiPO}_{4}$ deposition time was $45 \mathrm{~min}$ and the optimum working voltage was $1.2 \mathrm{~V}$. The trapping experiments showed that hydroxyl radicals $(\cdot \mathrm{OH})$ and superoxide radicals $\left(\bullet^{-}{ }_{2}^{-}\right)$were the major reactive species in PEC degradation process. The $\mathrm{BiPO}_{4} / \mathrm{rGO} / \mathrm{FTO}$ composite electrode showed the high stability and its methyl orange removal efficiency remained unchanged after four testing cycles. The reasons for the enhanced PEC efficiency of the Bi$\mathrm{PO}_{4} / \mathrm{rGO} / \mathrm{FTO}$ composite electrode was ascribed to the broad visible-light absorption range, the rapid transmission of photogenerated charges, and the mixed $\mathrm{BiPO}_{4}$ phase by the introduction of rGO in the composite electrode films.
\end{abstract}

(C) 2020, Dalian Institute of Chemical Physics, Chinese Academy of Sciences. Published by Elsevier B.V. All rights reserved.

\section{Introduction}

Photoelectrocatalytic (PEC) oxidation has been regarded as a potential approach of solving the problems of the organic pollution in aqueous solution using different semiconductor electrodes [1-3]. In the PEC process, the applied bias potential not only utilizes the electrochemical degradation of organic compounds but also improves the photocatalytic oxidation by accelerating the separation of electron-hole pairs. Early studies on photoelectrode materials for PEC reactions focused on $\mathrm{TiO}_{2}$. However, $\mathrm{TiO}_{2}$ can only absorb $3 \%-4 \%$ portion of UV light in sunlight due to the wide band gap (3.0-3.2 eV), which results in a very low PEC conversion efficiency. Consequently, a lot of visible-light-response photoelectrodes such as $\mathrm{WO}_{3}(2.6 \mathrm{eV})$, $\mathrm{Fe}_{2} \mathrm{O}_{3}(2.1 \mathrm{eV}), \mathrm{BiVO}_{4}(2.4 \mathrm{eV})$, have been widely developed to improve the utilization of solar energy [4-10]. Although many

\footnotetext{
* Corresponding author. E-mail: chendaimei@cugb.edu.cn

\# Corresponding author. E-mail: dinghao113@126.com

This work was partly supported by the National Natural Science Foundations of China (21577132, 21978276), the Fundamental Research Funds for the Central Universities (2652018326, 2652018298, 2652018297), and the Beijing Municipal Education Commission Key Science and Technology Project Fund (KZ201910853043).
}

DOI: S1872-2067(19)63520-5 | http://www.sciencedirect.com/science/journal/18722067 | Chin. J. Catal., Vol. 41, No. 2, February 2020 
decisive breakthroughs have been made after the continuous development of PEC technology, the energy conversion efficiency still cannot match the practical applications. Thus, it is challenging to develop photoelectrodes with excellent performance, high stability and low cost.

In 2010, Zhu et al. [11] reported a new indirect bandgap semiconductor photocatalyst $\mathrm{BiPO}_{4}$ with a band gap of $3.85 \mathrm{eV}$ for the first time. And its photocatalytic degradation of methyl blue (MB) performance was much higher than that of P25. The high photocatalytic activity of $\mathrm{BiPO}_{4}$ was ascribed to its high valence potential and the induction of $\mathrm{PO}_{4}{ }^{3-}$, which can promote the effective separation of electron-hole pairs. Due to the excellent photocatalytic oxidation property of $\mathrm{BiPO}_{4}$, it might be a promising material for environmental treatment in the practical applications. However, most of studies, until now, were limited to the traditional powder system photocatalytic technology. Inherent limitations, such as the stability and reuse of the catalysts, were seldom explored [12,13]. Recently, Zhang et al. [14] prepared $\mathrm{BiPO}_{4}$ photoelectrodes through one-step cathodic electrodeposition approach, and they reported that $\mathrm{BiPO}_{4}$ photoelectrode exhibited the excellent $\mathrm{PEC}$ degradation efficiency of organic pollutants. However, $\mathrm{BiPO}_{4}$ can only be excited in the ultraviolet region, which leads to the low utilization efficiency of sunlight. Our early work first prepared $\mathrm{Bi}$ OI/BiPO 4 /FTO composite electrode by a simple two-step electrodeposition method to improve the light utilization and the photocatalytic performance. The PEC activity of Bi$\mathrm{OI} / \mathrm{BiPO}_{4} / \mathrm{FTO}$ composite electrode for the removal of tetracycline under the visible light was 2.46 times as high as that of the $\mathrm{BiPO}_{4} /$ FTO electrode [15]. However, until now, a few papers have been reported about the preparation and properties of $\mathrm{BiPO}_{4}$ or $\mathrm{BiPO}_{4}$ based composite electrode. Searching for a new modification method to improve the PEC activity of $\mathrm{BiPO}_{4}$ electrode is still a challenge and need further study.

Graphene is a two-dimensional material composed of $s p^{2}$ single-layer hexagonal carbon. Due to unique thermodynamic, electrical, optical and mechanical functions, it has drawn wide attention from many fields. Moreover, its application in the photocatalytic technology has been widely concerned [16-22]. The modification of photocatalytic materials with graphene can enhance the conductivity and improve the photocatalytic activity due to the quicker transfer of electrons. In particular, the combination of semiconductors and graphene is widely recognized as one of the most promising electrodes in photoelectrocatalysis. Furthermore, the deposition of the graphene film on the conductive substrate can further serve a substrate for the uniform growth of the crystal of the photocatalyst material to obtain a graphene-modified composite electrode material. Many graphene-modified photoelectrode semiconductor materials, such as $\mathrm{ZnO} / \mathrm{rGO}, \mathrm{Cu}_{2} \mathrm{O} / \mathrm{rGO}, \mathrm{BiVO}_{4} / \mathrm{rGO}$ and $\mathrm{Fe}_{2} \mathrm{O}_{3} / \mathrm{rGO}$, showed the enhanced anode photocurrent and high PEC conversion efficiency [23-29].

In this work, a $\mathrm{BiPO}_{4} / \mathrm{rGO} / \mathrm{FTO}$ composite photoelectrode was prepared by a simple two-step electrodeposition method. The $\mathrm{BiPO}_{4} / \mathrm{rGO} / \mathrm{FTO}$ composite photoelectrode exhibits higher PEC activity than $\mathrm{BiPO}_{4} / \mathrm{FTO}$ photoelectrode. The introduction of rGO substrate not only increased the light absorption of $\mathrm{Bi}$ -
$\mathrm{PO}_{4}$ but also promoted the separation and transfer of photogenerated electron-holes pairs. The effects of working voltage and the electrodeposition time on the degradation efficiency of methyl orange were investigated. The mechanism of enhancing PEC activity of $\mathrm{BiPO}_{4} / \mathrm{rGO} / \mathrm{FTO}$ composite photoelectrode was discussed. This two-step simple electrodeposition method for the preparation of photoelectrode material might have a potential for scale production, and this composite photoelectrode might be a promising material for the environmental treatment.

\section{Experimental}

\subsection{Preparation of $\mathrm{rGO/FTO} \mathrm{electrodes}$}

All the used chemicals were analytical reagents. All electrochemical deposition experiments were carried out with an electrochemical workstation (CHI760E, Shanghai Huachen Instrument Co., Ltd.). The resistance of the fluorine-doped tin oxide (FTO) glass resistor was $15 \mathrm{ohms}$ and its area was $5 \times 2.5$ $\mathrm{cm}^{2}$. FTO glass modification was performed according to the following steps. FTO glass was soaked in ethanol for ultrasonic cleaning for $30 \mathrm{~min}$, soaked in $10 \%$ dilute nitric acid for $30 \mathrm{~min}$, and then thoroughly washed with the mixture of ethanol and distilled water, and dried at $60{ }^{\circ} \mathrm{C}$ in an oven. The electrolyte of graphene oxide was prepared according to the following steps. The graphene oxide powder was ultrasonically dispersed in $100 \mathrm{~mL}$ of ultrapure water to configure a solution having a concentration of $2 \mathrm{mg} / \mathrm{mL}$. Then, a certain amount of $\mathrm{LiClO}_{4}$ was added to reach a concentration of $0.12 \mathrm{M}$. Electrodeposition of rGO/FTO electrode was performed according to the following steps. rGO/FTO electrode material was prepared by electrodeposition reduction in a three-electrode system with saturated calomel electrode (SCE) as the reference electrode, FTO as working electrode, and Pt wire as the counter electrode. The rGO/FTO composite electrode material was obtained by electrodeposition for $150 \mathrm{~s}$ at a bias voltage of $-1.5 \mathrm{~V}$.

\subsection{Preparation of $\mathrm{BiPO}_{4} / \mathrm{rGO} / \mathrm{FTO}$ electrode}

$\mathrm{BiPO}_{4}$ precursor electrolyte solution was prepared according to the following steps. The electrodeposition process of this composite electrode is shown in Fig. 1. Firstly, $10 \mathrm{mM}$ ethylenediaminetetraacetic acid was dissolved into $100 \mathrm{~mL}$ of distilled water and then $10 \mathrm{mM}$ lanthanum nitrate pentahydrate was added to adjust the $\mathrm{pH}$ to below 1 . After that, 100 mM sodium phosphate decahydrate was added to adjust the $\mathrm{pH}$ to 1 and then $50 \mathrm{~mL}$ of $30 \%$ hydrogen peroxide was added. $\mathrm{BiPO}_{4} / \mathrm{rGO} / \mathrm{FTO}$ was prepared by the two-step electrodeposition method as following steps. In the three-electrode system, the saturated calomel electrode, the as prepared rGO/FTO electrode and the Pt wire were respectively used as the reference electrode, the working electrode, and the counter electrode. Before the electrodeposition of $\mathrm{BiPO}_{4}$, the $\mathrm{rGO} / \mathrm{FTO}$ electrode was rinsed with distilled water. The $\mathrm{BiPO}_{4} / \mathrm{rGO} / \mathrm{FTO}$ electrodes were prepared by electrodeposition of $\mathrm{BiPO}_{4}$ precursor at a bias of $-0.15 \mathrm{~V}$ for different deposition time. The 


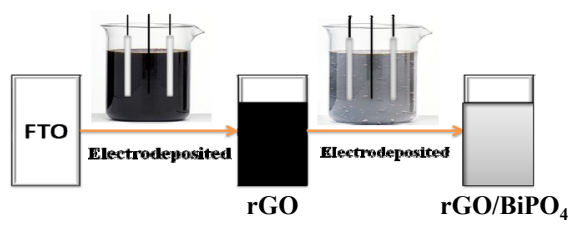

Fig. 1. Flow chart for the preparation of $\mathrm{BiPO}_{4} / \mathrm{rGO} / \mathrm{FTO}$ electrode.

obtained different $\mathrm{BiPO}_{4} / \mathrm{rGO} / \mathrm{FTO}$ electrodes were denoted as $\mathrm{BiPO}_{4} / \mathrm{rGO} / \mathrm{FTO}_{-x \min }(x=30,45$ and $60 \mathrm{~min})$, respectively. For the comparison, the $\mathrm{BiPO}_{4} / \mathrm{FTO}$ electrode was prepared by direct electrodeposition of $\mathrm{BiPO}_{4}$ precursor on the surface of FTO under the same conditions.

\subsection{Characterization}

The crystal structure of the electrode material was characterized by a German Bruker D8 Advance X-ray powder diffractometer (XRD). The $\mathrm{Cu} K \alpha$ target with $\lambda=1.5418$ has an instrument power of $3 \mathrm{kV}$, a voltage of $40 \mathrm{kV}$, a current of $20 \mathrm{~mA}$, and a scan range of $10^{\circ}$ to $70^{\circ}$. With the SU8010 cold field emission scanning electron microscope (SEM), under the acceleration voltage of the electron beam of $100 \mathrm{kV}$, the microscopic morphology of the electrode material was characterized. The morphology and crystal structure of the electrode material was characterized by an FEI Tecnai G ${ }^{2}$ F30 field emission transmission electron microscope (TEM) under an accelerating voltage of $200 \mathrm{kV}$. The Hitachi U-3900 UV-Vis spectrophotometer was used for the characterization of UV-vis diffuse reflectance spectra of the materials. The optical properties of the catalyst were characterized by the FLS980 fluorescence spectrometer (Edinburgh, UK) with an excitation wavelength of 225 $\mathrm{nm}$. The Raman spectra of the materials were characterized by HORIBA HR 800 laser confocal micro-Raman spectroscopy. The elemental composition of the material was characterized by an X-ray photoelectron spectrometer (PHI Quantern, Japanese).

\subsection{Catalytic performance test}

The photoelectric synergistic performance of materials was explored with an electrochemical workstation (CHI760E, Shanghai Huachen Instrument Co., Ltd.). In the three-electrode system, the saturated calomel electrode, the Pt wire and the $\mathrm{BiPO}_{4} / \mathrm{rGO} / \mathrm{FTO}$ electrode were used as the reference electrode, the counter electrode and the working electrode. With $10 \mathrm{ppm} \mathrm{MB}$ as an organic pollutant model, the PEC performance of the catalytic substrate was investigated. The light source was an ultraviolet lamp with an output intensity of 10 $\mathrm{W}$. The change in the concentration of the MB solution was detected with a Hitachi U-3900 UV-vis spectrophotometer under an absorption wavelength of $464 \mathrm{~nm}$. The volume of methyl orange solution in the quartz reactor was $100 \mathrm{~mL}$ and the effective area of the $\mathrm{BiPO}_{4} / \mathrm{rGO} / \mathrm{FTO}$ electrode was $5 \mathrm{~cm}^{2}$. The effect of deposition time of $\mathrm{BiPO}_{4}$ on the PEC activity of composite electrode materials was investigated under a certain bias voltage. The effects of different working voltages on the PEC activity of the electrodes were investigated. The photocatalytic, electrocatalytic and photoelectrocatalytic removal efficiencies of the methyl orange solution by $\mathrm{BiPO}_{4} / \mathrm{rGO} / \mathrm{FTO}$ electrodes were studied. Electrochemical tests such as transient response photocurrent density, electrochemical impedance spectroscopy and linear sweep volt-ampere curve were explored in the same three-electrode system with an electrochemical workstation. The electrolyte solution was $100 \mathrm{~mL}$ of $0.1 \mathrm{M} \mathrm{Na}_{2} \mathrm{SO}_{4}$.

\section{Results and discussion}

\subsection{Morpholog and structure}

The SEM images of $\mathrm{rGO} / \mathrm{FTO}, \mathrm{BiPO}_{4} / \mathrm{FTO}$ and Bi$\mathrm{PO}_{4} / \mathrm{rGO} / \mathrm{FTO}$ photoelectrode are shown in Fig. 2. Layered ultrathin graphene films, formed by the reduction of graphene oxide under a certain negative bias, were uniformly deposited on the FTO glass sheet (Fig. 2(a)). Pure $\mathrm{BiPO}_{4}$ nanorods were deposited on FTO glass (Fig. 2(b)). The morphology of pure $\mathrm{BiPO}_{4}$ shows the regular nanorod with a length of $1-2 \mu \mathrm{m}$ and a diameter of 400-600 nm. In Fig. 2(c) and 2(d), $\mathrm{BiPO}_{4}$ nanorods with the length at the range of $2-2.5 \mu \mathrm{m}$ and the diameter distribution range of $1.5-2 \mu \mathrm{m}$ were uniformly distributed on the rGO nanosheets. Compared with the pure $\mathrm{BiPO}_{4}$ nanorods, the $\mathrm{BiPO}_{4}$ nanorods in the composite became larger and irregular, and the ratio of length to diameter was increased. This fact showed that introduction of rGO affected the growth of $\mathrm{BiPO}_{4}$ crystals.

In order to further explore the crystal structure of the electrode material, the prepared $\mathrm{BiPO}_{4} / \mathrm{rGO} / \mathrm{FTO}$ materials were characterized by XRD. It can be seen that the characteristic peak of graphene oxide at $2 \theta=11^{\circ}$ is absent in pure rGO/FTO, indicating that the graphene oxide was reduced into the rGO during electrodeposition (Fig. 3). The major characteristic peaks of $\mathrm{BiPO}_{4}$ such as (100), (101), (110), (200) and (102) were observed in the XRD patterns, which were consistent with the standard PDF card of hexagonal $\mathrm{BiPO}_{4}$ (JCPDS No. 15-0766). For the $\mathrm{BiPO}_{4} / \mathrm{rGO} / \mathrm{FTO}$ composite photoelectrode, the characteristic peaks of monoclinic phases $\mathrm{BiPO}_{4}$ at (011), (111), (200), (120), (202), (220) and (022) (JCPDS No. 15-0767) can also be observed, indicating that the formation of mixture crystal structure of hexagonal and monoclinic phases in this composite electrode. This fact shows that the introduc-

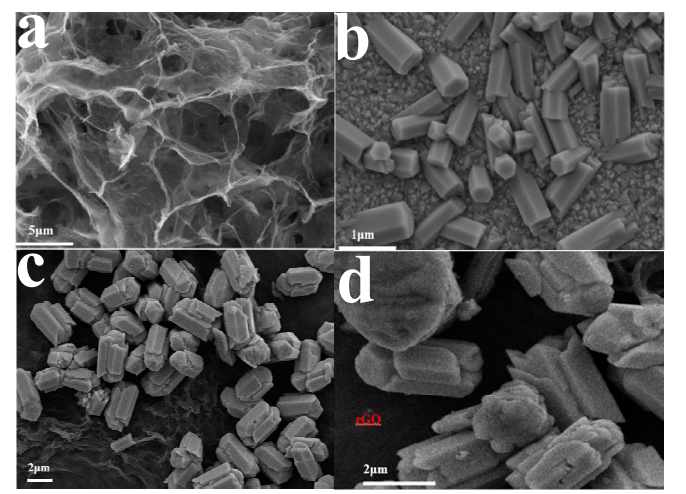

Fig. 2. SEM images of $\mathrm{rGO} / \mathrm{FTO}(\mathrm{a}), \mathrm{BiPO}_{4} / \mathrm{FTO}$ (b), $\mathrm{rGO} / \mathrm{BiPO}_{4} / \mathrm{FTO}$ $(\mathrm{c}, \mathrm{d})$. 


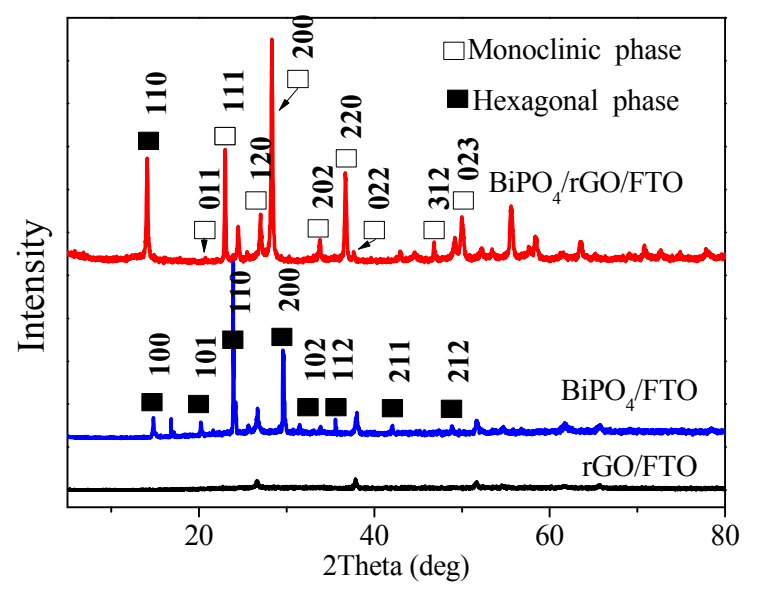

Fig. 3. XRD patterns of $\mathrm{rGO} / \mathrm{FTO}, \mathrm{BiPO}_{4} / \mathrm{FTO}$ and $\mathrm{BiPO}_{4} / \mathrm{rGO} / \mathrm{FTO}$ electrodes.

tion of rGO might affect the crystal growth of $\mathrm{BiPO}_{4}$, resulting in the phase transfer from hexagonal crystal to monoclinic crystal.

The TEM and HRTEM images of $\mathrm{BiPO}_{4} / \mathrm{rGO} / \mathrm{FTO}$ composite photoelectrodes were shown in Fig. 4. $\mathrm{BiPO}_{4}$ nanorods were uniformly deposited on the layer rGO film. The lattice fringes of $\mathrm{BiPO}_{4}$ were observed in HRTEM images of the $\mathrm{BiPO}_{4} / \mathrm{rGO} / \mathrm{FTO}$ composite photoelectrode (Fig. 4(c)). The diffraction speckle pattern obtained by Fourier transform (Fig. 4(d)) showed that the lattice spacings correspond to (111), (220) and (022) of monoclinic phase of $\mathrm{BiPO}_{4}$ crystal were respectively 0.3514, 0.2383 , and $0.2328 \mathrm{~nm}$, which were consistent with XRD results.

The Raman spectra of GO, rGO, $\mathrm{BiPO}_{4}$ and $\mathrm{BiPO}_{4} / \mathrm{rGO} / \mathrm{FTO}$ composite photoelectrodes were shown in Fig. 5. The characteristic peaks of graphene (D peak and G peak) occurred at 1342 and $1587 \mathrm{~cm}^{-1}$ in the Raman spectra of GO and rGO. The $\mathrm{D}$ peak indicated the formation of defects in the associated graphite layer structure due to the introduction of oxygen-containing functional groups, whereas the $\mathrm{G}$ band indicated the symmetry and crystallinity of graphene. Compared with GO, rGO showed the higher $I_{\mathrm{D}} / I_{\mathrm{G}}$ ratio, indicating that $\mathrm{GO}$ was reduced to $\mathrm{rGO}$ during electrodeposition. The $\mathrm{O}-\mathrm{Bi}-\mathrm{O}$ vibration

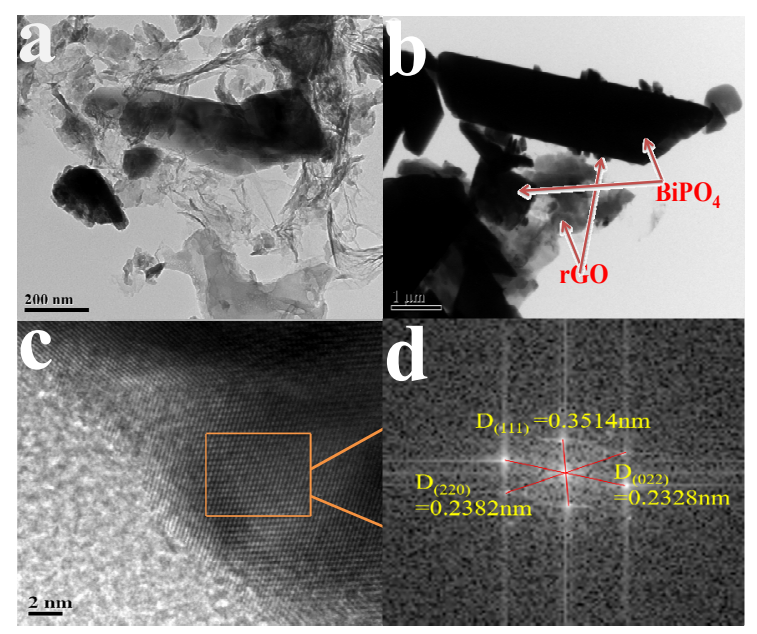

Fig. 4. TEM (a,b), HRTEM (c) images, and Fourier transform spectra (d) of $\mathrm{BiPO}_{4} / \mathrm{rGO} / \mathrm{FTO}$ electrode.

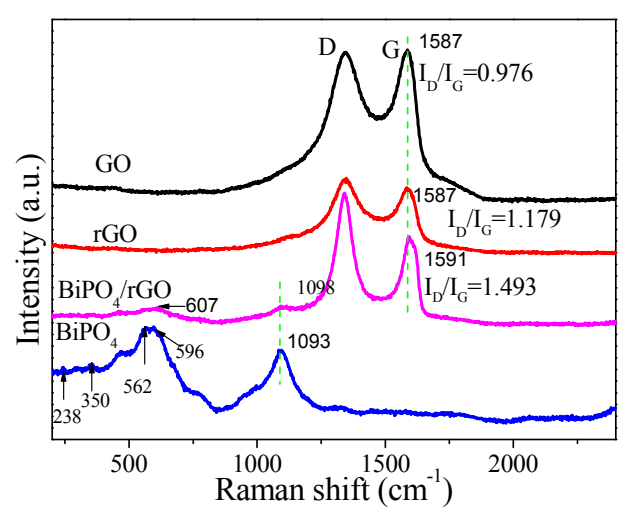

Fig. 5. Raman spectra of $\mathrm{GO}, \mathrm{rGO}, \mathrm{BiPO}_{4} / \mathrm{rGO}$ and $\mathrm{BiPO}_{4}$ electrodes.

peak of $\mathrm{BiPO}_{4}$ appeared at $238 \mathrm{~cm}^{-1}$, and the vibration peaks of $\mathrm{PO}_{4}{ }^{3+}$ were observed at 350,562, 569, and $1093 \mathrm{~cm}^{-1}$. The composite electrode showed the vibration peak of $\mathrm{PO}_{4}{ }^{3+}$ in $\mathrm{Bi}-$ $\mathrm{PO}_{4}$ at 607 and $1098 \mathrm{~cm}^{-1}$ and the characteristic D peak and G peak of rGO at 1342 and $1587 \mathrm{~cm}^{-1}$, indicating that two materials of $\mathrm{rGO}$ and $\mathrm{BiPO}_{4}$ were well combined in the Bi$\mathrm{PO}_{4} / \mathrm{rGO} / \mathrm{FTO}$ composite photoelectrode. Moreover, the value of $I_{\mathrm{D}} / I_{\mathrm{G}}$ was further increased indicating that the reduction degree of graphene was further improved during the electrodeposition process of $\mathrm{BiPO}_{4}$. These changes increased the conductivity of $\mathrm{rGO}$, accelerated the transfer of photogenerated charges of $\mathrm{BiPO}_{4}$ and enhanced the PEC activity consequently. In addition, the $\mathrm{G}$ peak of graphene in the $\mathrm{BiPO}_{4} / \mathrm{rGO} / \mathrm{FTO}$ electrode shifted from 1587 to $1591 \mathrm{~cm}^{-1}$, indicating that a strong chemical interaction occurred between $\mathrm{rGO}$ and $\mathrm{BiPO}_{4}$.

The XPS broad spectra of $\mathrm{BiPO}_{4} / \mathrm{FTO}$ and $\mathrm{BiPO}_{4} / \mathrm{rGO} / \mathrm{FTO}$ photoelectrodes and the narrow spectra of $\mathrm{Bi} 4 f$, $\mathrm{O} 1 \mathrm{~s}$ and $\mathrm{C} 1 \mathrm{~s}$ are shown in Fig. 6. The peaks of Bi, P, O, C and other elements were observed in the wide spectra of two electrode materials (Fig. 6(a)). The two peaks of 159.4 and $164.7 \mathrm{eV}$ in the Bi$\mathrm{PO}_{4} /$ FTO electrode respectively represented the $\mathrm{Bi} 4 f_{7 / 2}$ and $\mathrm{Bi}$ $4 f_{5} / 2$ peaks of the $\mathrm{Bi}-0$ bond (Fig. $6(\mathrm{~b})$ ). In the $\mathrm{BiPO}_{4} / \mathrm{rGO} / \mathrm{FTO}$ composite electrode, the peaks of $\mathrm{Bi}-\mathrm{O}$ bond shifted to 160.1 and $165.4 \mathrm{eV}$, respectively. The increase in $\mathrm{Bi}^{3+}$ binding energy in $\mathrm{BiPO}_{4} / \mathrm{rGO} / \mathrm{FTO}$ composite photoelectrodes might be ascribed to the transfer of the outer electrons of $\mathrm{BiPO}_{4}$ to $\mathrm{rGO}$. It suggested that the electron cloud density of $\mathrm{BiPO}_{4}$ was decreased. In the $01 s$ narrow spectra of $\mathrm{BiPO}_{4} / \mathrm{rGO} / \mathrm{FTO}$ and $\mathrm{BiPO}_{4} / \mathrm{FTO}$ photoelectrodes, the peaks at 530 and $532 \mathrm{eV}$ (Fig. 6(c)) corresponded to $\mathrm{Bi}-\mathrm{O}$ and $\mathrm{C}-\mathrm{O}$ peaks. In the narrow spectrum of $\mathrm{C} 1 s$ of the $\mathrm{BiPO}_{4} / \mathrm{FTO}$ and $\mathrm{BiPO}_{4} / \mathrm{rGO} / \mathrm{FTO}$ composite photoelectrodes, the peaks at 284.8 and $286.6 \mathrm{eV}$ corresponded to the $\mathrm{C}-\mathrm{C}$ and $\mathrm{C}-\mathrm{O}$ bonds, respectively. However, it was odd that the peak of the $\mathrm{C}-\mathrm{O}$ bond occurred in the $\mathrm{Bi}$ $\mathrm{PO}_{4} /$ FTO photoelectrode. It was conjectured that some residual organic matters in EDTA did not removed clearly. Furthermore, compared with the $\mathrm{BiPO}_{4} / \mathrm{FTO}$ electrode, the peak areas of the $\mathrm{C}-\mathrm{C}$ and $\mathrm{C}-\mathrm{O}$ bonds increased, which was due to the present of rGO in the composite. The $01 s$ narrow spectra of Bi$\mathrm{PO}_{4} / \mathrm{rGO} / \mathrm{FTO}$ and $\mathrm{BiPO}_{4} / \mathrm{FTO}$ photoelectrode at 530 and 532 

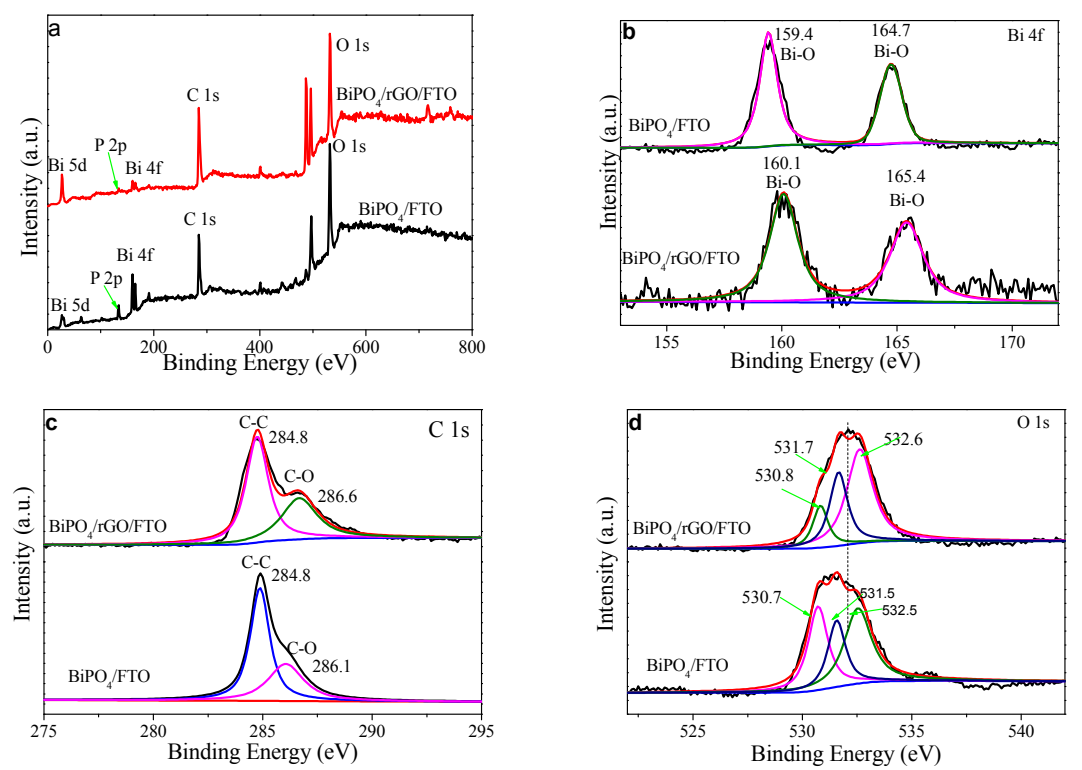

Fig. 6. XPS broad spectra (a), Bi $4 f(b), 01 s(c)$, and C $1 s$ (d) spectra of $\mathrm{BiPO}_{4} / \mathrm{FTO}$ and $\mathrm{BiPO}_{4} / \mathrm{rGO} / \mathrm{FTO}$ electrodes.

$\mathrm{eV}$ were ascribed to $\mathrm{Bi}-\mathrm{O}$ and $\mathrm{C}-\mathrm{O}$ peak, respectively (Fig. 6(d)). Similarly, the $\mathrm{C}-0$ peak at $532.5 \mathrm{eV}$ in the $\mathrm{BiPO}_{4} / \mathrm{FTO}$ electrode was mainly ascribed to residual organic matters in EDTA during the synthesis of photoelectrode. The $\mathrm{Bi}-\mathrm{O}$ peak area at $530.8 \mathrm{eV}$ was decreased in the $\mathrm{BiPO}_{4} / \mathrm{rGO} / \mathrm{FTO}$ composite photoelectrode, whereas the $\mathrm{C}-\mathrm{O}$ peak area at $532.5 \mathrm{eV}$ was increased because the introduction of rGO could give occasion to the increase of the content of $\mathrm{C}-\mathrm{O}$ bond.

The UV-vis diffuse reflectance spectra (DRS) of $\mathrm{BiPO}_{4} / \mathrm{FTO}$ photoelectrode and $\mathrm{BiPO}_{4} / \mathrm{rGO} / \mathrm{FTO}$ composite photoelectrode under the different disposition time was shown in Fig. 7. $\mathrm{BiPO}_{4}$ had light absorption only in the ultraviolet region and the absorption edge was about $375 \mathrm{~nm}$. When the $\mathrm{BiPO}_{4}$ nanorods were electrodeposited on the substrate of the $\mathrm{rGO}$, the UV-vis diffuse absorption edge of the $\mathrm{BiPO}_{4} / \mathrm{rGO} / \mathrm{FTO}$ composite photoelectrode was red-shifted. In the composite electrode, the light absorption intensity and range varied with $\mathrm{BiPO}_{4}$ electrodeposition time. When deposition time of $\mathrm{BiPO}_{4}$ was $45 \mathrm{~min}$, the obtained $\mathrm{BiPO}_{4} / \mathrm{rGO} / \mathrm{FTO}$ composite photoelectrode had the largest redshift range and photoresponse range, which improve the visible absorption of $\mathrm{BiPO}_{4} / \mathrm{FTO}$ photoelectrode.

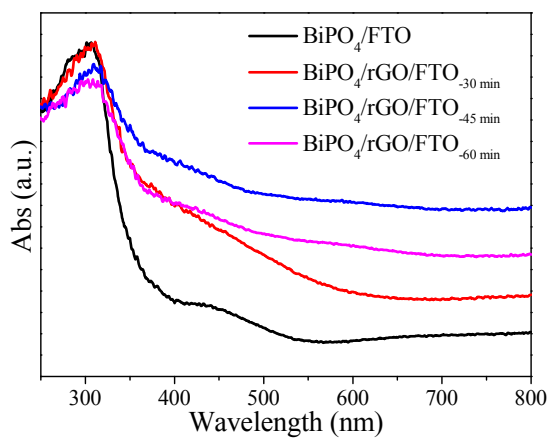

Fig. 7. UV-vis diffuse reflectance spectra of $\mathrm{BiPO}_{4} / \mathrm{rGO} / \mathrm{FTO}$ and $\mathrm{Bi}$ $\mathrm{PO}_{4} /$ FTO photoelectrodes.

\subsection{Photoelectrochemical performance}

In order to explore the effects of $\mathrm{rGO}$ and the $\mathrm{BiPO}_{4}$ deposition time on the PEC activity of the $\mathrm{BiPO}_{4}$ nanorod photoelectrode, the PEC degradation experiments were carried out with $10 \mathrm{ppm}$ methyl orange as the model pollutant and $10 \mathrm{~W} \mathrm{UV}$ lamp as the light source. The $\mathrm{BiPO}_{4} / \mathrm{rGO} / \mathrm{FTO}$ composite electrode had a much better degradation effect on methyl orange than the $\mathrm{BiPO}_{4} / \mathrm{FTO}$ photoelectrode under a constant applied bias voltage of $1.2 \mathrm{~V}$ (Fig. 8(a)), indicating that the introduction of film greatly enhanced the PEC degradation activity of $\mathrm{BiPO}_{4}$ nanorods. As given in Fig. 8(b), the degradation reaction rate constant reactions of methyl orange by $\mathrm{BiPO}_{4} / \mathrm{rGO} / \mathrm{FTO}$ composite electrode under the different deposition time. All the composite photoelectrodes have the higher PEC activity than $\mathrm{BiPO}_{4}$ nanorod photoelectrode. When the $\mathrm{BiPO}_{4}$ deposition time was $45 \mathrm{~min}$, the $\mathrm{BiPO}_{4} / \mathrm{rGO} / \mathrm{FTO}$ electrode had the optimal reaction rate constant $(k=0.281)$, which was 4.3 times higher than that of the $\mathrm{BiPO}_{4} / \mathrm{FTO}$ electrode $(k=0.065)$. Further increasing the loading of $\mathrm{BiPO}_{4}$, the reaction rate began to decrease. The reason is that the overloading of $\mathrm{BiPO}_{4}$ might affect the light absorption of the underlying material and thus decreased the PEC activity.

It was given that the effect of working voltage on the PEC activity of $\mathrm{BiPO}_{4} / \mathrm{rGO} / \mathrm{FTO}_{-45}$ min composite photoelectrode under different applied operating voltages. The operating voltage varied from 0.6 to $1.4 \mathrm{~V}$. The removal rate of methyl orange increased at first and then decreased as the operating voltage increased. At the applied working voltage of $1.2 \mathrm{~V}$, the $\mathrm{Bi}$ $\mathrm{PO}_{4} / \mathrm{rGO} / \mathrm{FTO}$ composite photoelectrode had the optimum removal rate of methyl orange, indicating that $1.2 \mathrm{~V}$ was the optimum applied operating voltage for the PEC degradation. In the PEC degradation of pollutants, the applied bias voltage was one of the important factors affecting the degradation perfor- 

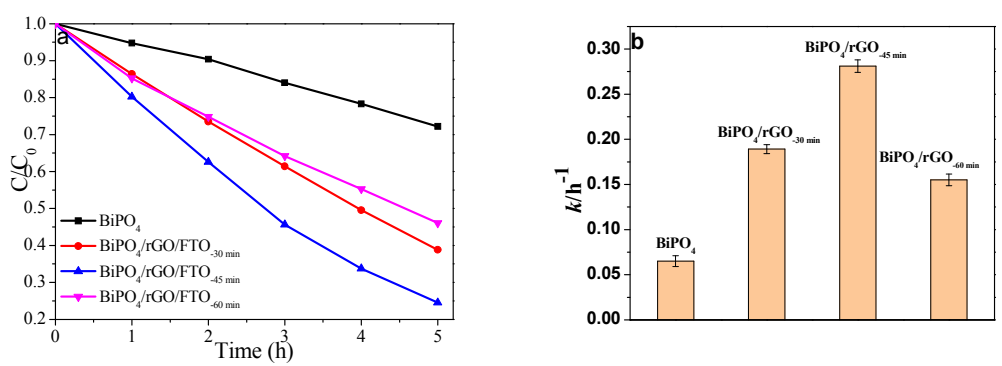

Fig. 8. PEC activity (a) and reaction rate constants (b) of $\mathrm{BiPO}_{4} / \mathrm{FTO}$ and $\mathrm{BiPO}_{4} / \mathrm{rGO} / \mathrm{FTO}$ composite photoelectrodes under different deposition time.
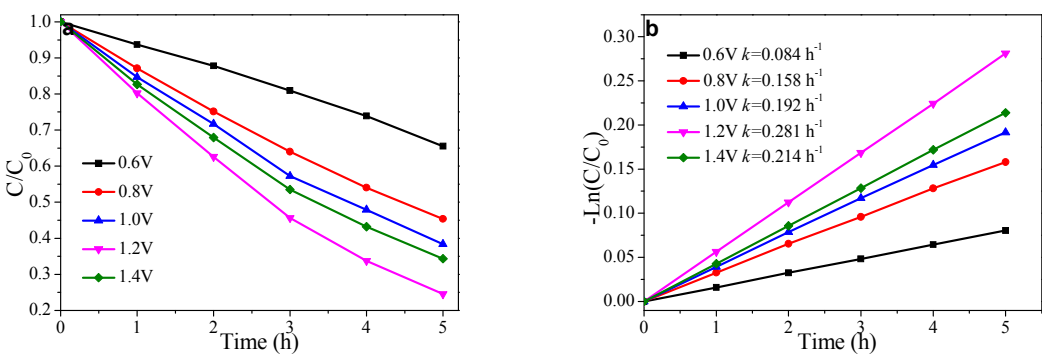

Fig. 9. PEC activity (a) and kinetic curves (b) of $\mathrm{BiPO}_{4} / \mathrm{rGO}_{/} \mathrm{FTO}_{-45}$ min electrode under the different external working voltage.

mance. The bias voltage could promote the transfer of photogenerated electrons to the platinum wire electrode through the external circuit. The electrons were effectively separated from holes in space, thus enhancing the quantum efficiency of photoelectroncatalysts. When the applied voltage reaches a certain value, the composite photoelectrode of the photogenerated electrons experienced directional movement and most of the photogenerated electrons were separated from holes to form a saturated photocurrent resulting in optimal photoelectric catalytic efficiency. When the voltage exceeded the optimum value, the space charge layer and the Hertz layer of the catalyst might be redistributed due to excessive working bias voltage, thus reducing photo-generated carriers and the PEC activity.

In order to prove the photoelectric synergy of Bi$\mathrm{PO}_{4} / \mathrm{rGO} / \mathrm{FTO}$ composite photoelectrode, the photocatalytic, electrocatalytic and photoelectrocatalytic activities of this composite material were compared. After the $10 \mathrm{ppm}$ methyl orange solution was irradiated for $5 \mathrm{~h}$ with a $10 \mathrm{~W}$ UV lamp without the catalyst, the pollutant concentration was not significantly changed, indicating that the self-degradation of methyl orange solution under the irradiation of UV lamp could be ruled out (Fig. 10(a)). The photocatalytic degradation rate of methyl orange by $\mathrm{BiPO}_{4} / \mathrm{rGO} / \mathrm{FTO}$ composite photoelectrode was only about $20 \%$ after $5 \mathrm{~h}$ under UV light irradiation. The electro-catalysis degradation rate of methyl orange was about $50 \%$ after $5 \mathrm{~h}$ under the bias voltage of $1.2 \mathrm{~V}$. The PEC degradation efficiency of methyl orange in $\mathrm{BiPO}_{4} / \mathrm{rGO} / \mathrm{FTO}$ composite photoelectrode was increased to about $80 \%$. However, the reaction rate constant of the $\mathrm{BiPO}_{4} / \mathrm{rGO} / \mathrm{FTO}$ composite photoelectrode was $0.281 \mathrm{k} / \mathrm{h}^{-1}$, which was about 2 times higher than the electrocatalytic reaction rate constant and 5 times higher than photocatalytic reaction rate constant (Fig. 10(b)). The reaction kinetic constants indicated that the PEC degradation rate of methyl orange had the synergistic effect for the removal of organic compounds [30].

\subsection{Enhancement mechanism of the photoelectrocatalytic performance}

To further demonstrate the enhancement effect of photogenerated electrons on the synergistic catalytic performance, transient photocurrent response and electrochemical imped-
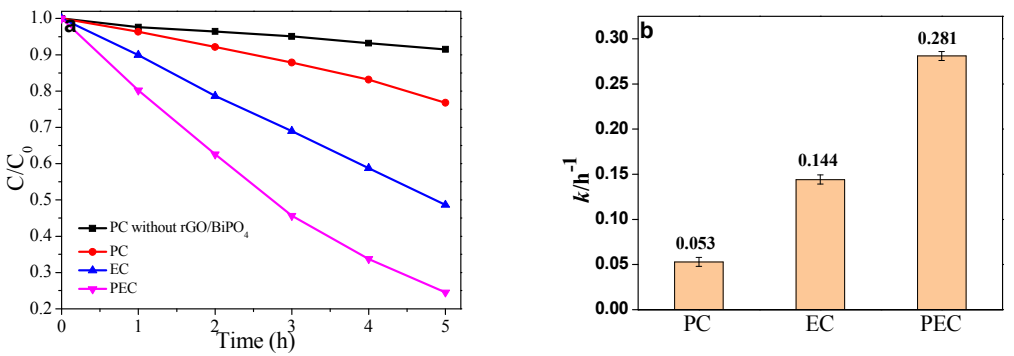

Fig. 10. Photocatalytic, electrocatalytic and photoelectrocatalytic activities (a) of $\mathrm{BiPO}_{4} / \mathrm{rGO} / \mathrm{FTO}$ composite photoelectrodes and reaction rate constants (b). 

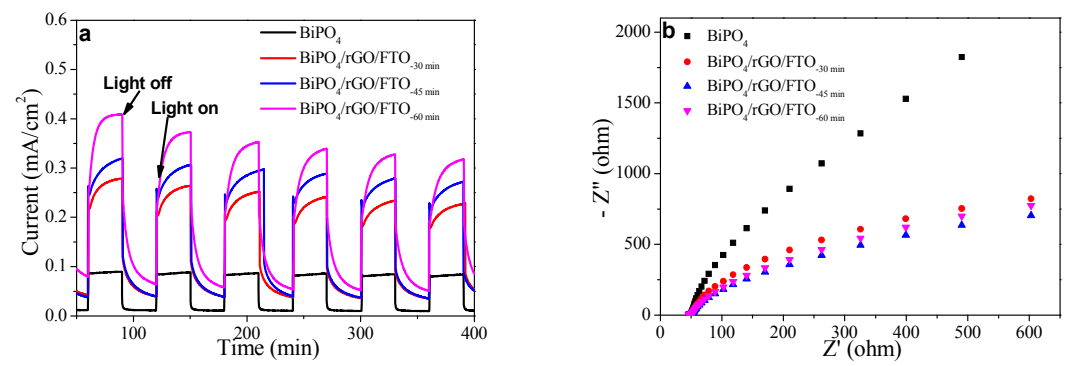

Fig. 11. (a) Transient photocurrent response diagram and (b) electrochemical impedance spectra of $\mathrm{BiPO}_{4} / \mathrm{FTO}, \mathrm{BiPO}_{4} / \mathrm{rGO} / \mathrm{FTO}_{-30}$ min, $\mathrm{Bi}_{-}$

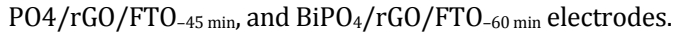

ance spectroscopy (EIS) tests were performed. The photocurrent response intensity of the $\mathrm{BiPO}_{4} /$ FTO photoelectrode was about $0.1 \mathrm{~mA} / \mathrm{cm}^{2}$ (Fig. 11(a)). The $\mathrm{BiPO}_{4} / \mathrm{rGO} / \mathrm{FTO}_{-45} \mathrm{~min}$ composite photoelectrode had the optimal photocurrent response intensity of about $0.4 \mathrm{~mA} / \mathrm{cm}^{2}$, which was 4 times that of the $\mathrm{BiPO}_{4}$ electrode. The EIS (Fig. 11(b)) also showed that the $\mathrm{BiPO}_{4} / \mathrm{rGO}_{\mathrm{FTO}}-45$ min composite photoelectrode had the smallest internal resistance and efficient electron transfer. The results were consistent with the PEC activities of prepared electrodes. The composite electrodes had a stronger light absorption intensity and a wider light absorption range than the pure $\mathrm{BiPO}_{4}$ electrode. The rGO film as a conductive medium could increase the conductivity of the electrode and accelerate the electron-hole separation, thus enhancing the catalytic activity of the photoelectric composite electrode material.

Based on the linear electrochemical voltammetric curve (LSV), the photoelectrochemical properties of various electro-optical materials were compared and shown in Fig. 12. The pure $\mathrm{BiPO}_{4}$ /FTO nanorod photoelectrode had the lowest photocurrent density under UV light in the bias voltage range of $0-1.8 \mathrm{~V}$. The introduction of the rGO film significantly increased the photocurrent response density of the photoelectrode, indicating that graphene accelerated the separation of photogenerated carriers. The results of LSV were agreed with the photocurrent density results.

As shown in Fig. 13, the $\mathrm{BiPO}_{4} / \mathrm{FTO}$ thin film electrode had the strongest PL peak. After the combination of rGO (Bi$\mathrm{PO}_{4} / \mathrm{rGO} / \mathrm{FTO}$ ), the PL peak intensities were greatly reduced, indicating that the rGO film accelerated the separation and transfer of electron-hole pairs due to its excellent conductivity.

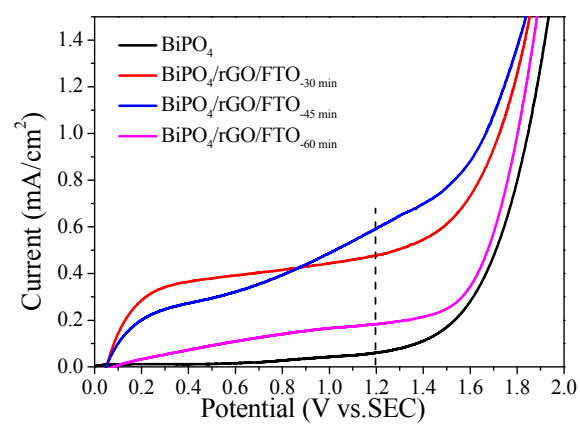

Fig. 12. Linear sweep voltammetry curves of $\mathrm{BiPO}_{4} / \mathrm{FTO}, \mathrm{Bi}$ $\mathrm{PO}_{4} / \mathrm{rGO} / \mathrm{FTO}_{-30} \mathrm{~min}, \mathrm{BiPO}_{4} / \mathrm{rGO} / \mathrm{FTO}_{-45} \mathrm{~min}$ and $\mathrm{BiPO}_{4} / \mathrm{rGO} / \mathrm{FTO}_{-60}$ min electrodes under UV light irradiation.
The $\mathrm{BiPO}_{4} / \mathrm{rGO}_{\mathrm{FTO}}-45$ min composite photoelectrode had the lowest PL peak and the lowest electron-hole recombination efficiency, indicating the highest PEC activity.

The main active species during the degradation process were determined by free radical trapping experiments, and then the mechanism of photoelectric synergistic catalysis could be indirectly inferred. The degradation experiments were carried out under a 10W UV lamp and a bias voltage of $1.2 \mathrm{~V}$. Methanol (MA), isopropanol (IPA) and p-benzoquinone (BQ) were used as the traps for the hole $\left(\mathrm{h}^{+}\right)$, hydroxyl radical $(\cdot \mathrm{OH})$ and superoxide radical $\left(\cdot \mathrm{O}_{2}^{-}\right)$trapping agent, respectively. There was no significant decrease in the removal efficiency of methyl orange by $\mathrm{BiPO}_{4} / \mathrm{rGO} / \mathrm{FTO}$ composite photoelectrode after adding methanol (Fig. 14), indicating that holes $\left(\mathrm{h}^{+}\right)$did not directly participate in the degradation of methyl orange and was not the main active species in the PEC reaction. However, the degradation efficiency of $\mathrm{BiPO}_{4} / \mathrm{rGO} / \mathrm{FTO}$ composite photoelectrode decreased significantly after adding IPA, indicating that $\cdot \mathrm{OH}$ was a main active species in the $\mathrm{PEC}$ reaction process. The removal efficiency of methyl orange by $\mathrm{BiPO}_{4} / \mathrm{rGO} / \mathrm{FTO}$ composite photoelectrode decreased significantly after the addition of p-benzoquinone, indicating that $\cdot \mathrm{O}_{2}{ }^{-}$was another main active species in the PEC reaction process. From the above results, it could be inferred that holes did not directly play a role in the degradation of methyl orange. These active substances $\left(\cdot \mathrm{OH}\right.$ and $\left.\cdot \mathrm{O}_{2}{ }^{-}\right)$dominated the photovoltaic synergistic catalytic reaction during the catalytic process.

Based on the experimental results, the mechanism of the $\mathrm{BiPO}_{4} / \mathrm{rGO} / \mathrm{FTO}$ electrode for the enhancement of the PEC activity was tentatively explained and shown in the Fig. 15. A large number of electron-hole pairs were generated in $\mathrm{BiPO}_{4}$

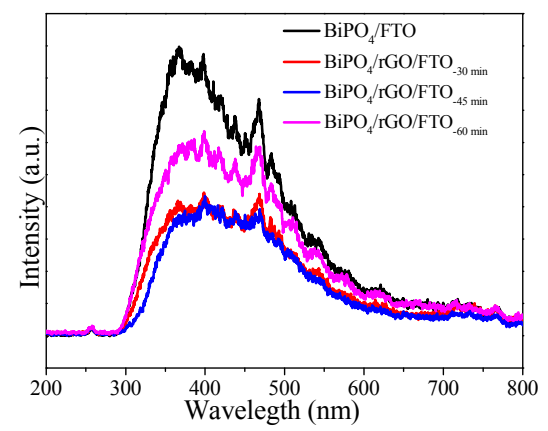

Fig. 13. $\mathrm{PL}$ spectra of $\mathrm{BiPO}_{4} / \mathrm{FTO}, \mathrm{BiPO}_{4} / \mathrm{rGO}^{-\mathrm{FTO}_{-30}} \mathrm{~min}, \mathrm{Bi}-$ $\mathrm{PO}_{4} / \mathrm{rGO} / \mathrm{FTO}_{-45} \mathrm{~min}$, and $\mathrm{BiPO}_{4} / \mathrm{rGO}_{/} \mathrm{FTO}_{-60 \mathrm{~min}}$ electrodes. 


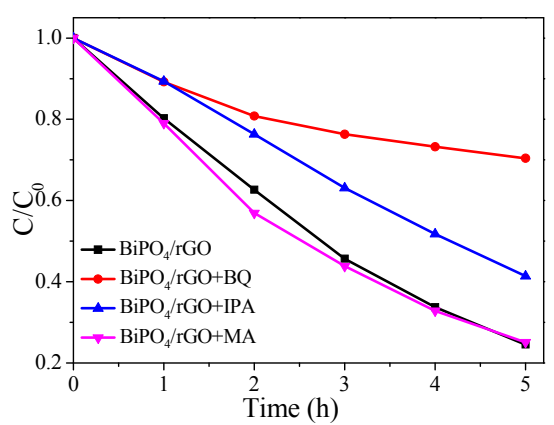

Fig. 14. Active species trapping experiment for the degradation of methyl orange with the $\mathrm{BiPO}_{4} / \mathrm{rGO}_{/} \mathrm{FTO}_{-45}$ min electrodes.

under the UV light irradiation. As a good electron conductor, graphene rapidly transferred the photogenerated electrons to the FTO. The applied bias voltage formed an electric field to transfer electrons through the FTO glass to the Pt electrode, further accelerating electron-hole separation and transfer. A large number of photogenerated electrons were accumulated on the Pt electrode and reacted with adsorbed oxygen molecules to produce $\cdot \mathrm{O}_{2}{ }^{-}$active species, which ultimately degraded organic pollutants. Correspondingly, the photogenerated holes generated by $\mathrm{BiPO}_{4}$ could react with water molecules in the solution to produce another active species $\bullet \mathrm{OH}$. The $\bullet \mathrm{OH}$ has strong oxidizing properties and can rapidly degrade pollutants. On the other hand, the introduction of rGO led to the $\mathrm{BiPO}_{4}$ transition from the hexagonal phase to the monoclinic phase. The formation of a mixed crystal phase contributed to the separation of electrons and holes. In addition, graphene had a conjugated structure with a large $\pi$ bond, which helped to increase the adsorption of pollutants on the catalyst surface and accelerated the photocatalytic oxidation reaction. The PEC activity of the $\mathrm{BiPO}_{4} / \mathrm{rGO} / \mathrm{FTO}$ composite photoelectrode finally enhanced [31].

\subsection{Stability of $\mathrm{BiPO}_{4} / \mathrm{rGO} / \mathrm{FTO}$ electrodes}

A cyclic experiment was carried out in a static system to further investigate the stability of the $\mathrm{BiPO}_{4} / \mathrm{rGO} / \mathrm{FTO}$ electrode in the degradation process of methyl orange. From Fig. 16 , the photoelectric catalytic oxidation effect of the Bi$\mathrm{PO}_{4} / \mathrm{rGO} / \mathrm{FTO}$ electrode did not decrease significantly after four cycles of degradation reaction of $20 \mathrm{~h}$, indicating that the

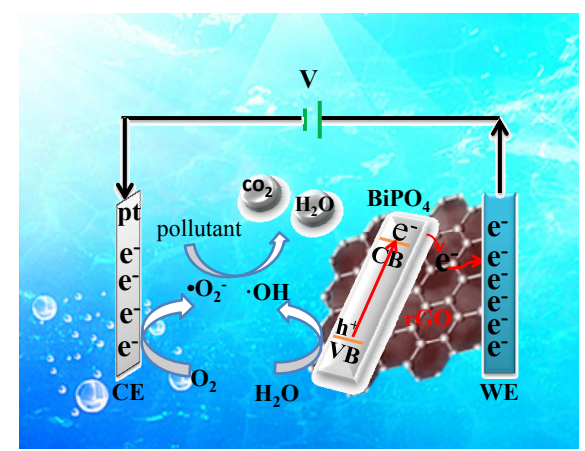

Fig. 15. Photoelectrocatalysis mechanism of $\mathrm{BiPO}_{4} / \mathrm{rGO} / \mathrm{FTO}$ electrodes.

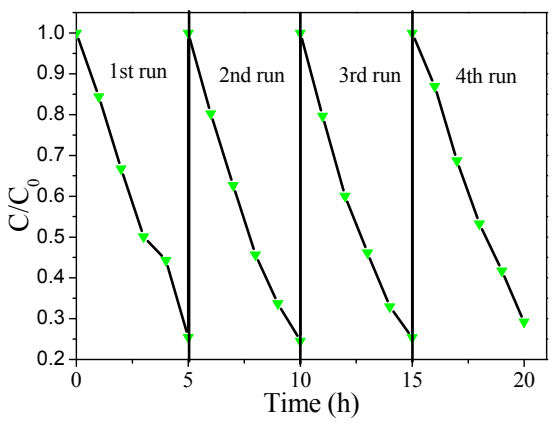

Fig. 16. Cycle stablity test of methyl orange degradation with the $\mathrm{Bi}$ $\mathrm{PO}_{4} / \mathrm{rGO} / \mathrm{FTO}_{-45}$ min electrodes.

$\mathrm{BiPO}_{4} / \mathrm{rGO} / \mathrm{FTO}$ electrode had the good stability.

\section{Conclusions}

In this work, $\mathrm{BiPO}_{4} / \mathrm{rGO} / \mathrm{FTO}$ composite photoelectrodes were prepared by a simple two-step electrodeposition method. The composite photoelectrodes had the excellent photoelectrocatalysis performance compared to the $\mathrm{BiPO}_{4} / \mathrm{FTO}$ electrode, Graphene, as a good electron conductor, could accelerate the separation and transfer of electrons-hole pairs and improve light absorption of $\mathrm{BiPO}_{4} / \mathrm{FTO}$ electrode. In addition, the introduction of rGO led to the formation of mixture phase of $\mathrm{BiPO}_{4}$, further promoting the separation of photogenerated charges. Free radical inactivation experiments showed that $\cdot \mathrm{OH}$ and $\cdot \mathrm{O}_{2}{ }^{-}$ might be the main active species in the photoelectrocatalytic degradation process. The composite electrode material exhibited extremely high stability and its photoelectric synergistic catalytic oxidation effect was not decreased significantly after four cycles of degradation reaction for $20 \mathrm{~h}$. The prepared composite electrode has great application prospects in the field of photoelectrocatalytic oxidation for practical water purification.

\section{Acknowledgment}

This work was partly supported by the National Natural Science Foundation of China (21577132, 21978276), the Fundamental Research Funds for the Central Universities (2652018326, 2652018298, 2652018297), and the Beijing Municipal Education Commission Key Science and Technology Project Fund (KZ201910853043).

\section{References}

[1] S. Chai, G. Zhao, Y. N. Zhang, Y, Wang, F, Nong, Environ. Sci. Technol., 2012, 46, 10182-10190.

[2] T. Li, X. Li, Q. Zhao, Y. Shi, W. Teng, Appl. Catal. B, 2014, 156, 362-370.

[3] C. Zhai, M. Zhu, D. Bin, H. Wang, Y. Du, C. Wang, P. Wang, ACS Appl. Mater. Interfaces, 2014, 6, 17753-17761.

[4] P. Chatchai, A. Y. Nosaka, Y. Nosaka, Electrochim. Acta, 2013, 94, 314-319.

[5] H. Zheng, J. Z. Ou, M. S. Strano, R. B. Kaner, A. Mitchell, K. Kalan- 


\title{
Graphical Abstract
}

Chin. J. Catal., 2020, 41: 302-311 doi: S1872-2067(19)63520-5

\section{Preparation of $\mathrm{BiPO}_{4} /$ graphene photoelectrode and its photoelectrocatalyitic performance}

Zetian He, Sen Liu, Yi Zhong, Daimei Chen *, Hao Ding*, Jiao Wang, Gaoxiang Du, Guang Yang, Qiang Hao

China University of Geosciences, China; Beijing Polytechnic College; University of Technology Sydney, Australia

$\mathrm{A} \mathrm{BiPO}_{4} / \mathrm{rGO} / \mathrm{FTO}$ composite photoelectrode was prepared by a simple two-step electrodeposition method. The $\mathrm{BiPO}_{4} / \mathrm{rGO} / \mathrm{FTO}$ composite photoelectrode exhibits the higher PEC activity than $\mathrm{BiPO}_{4} / \mathrm{FTO}$ photoelectrode and it has good stability.

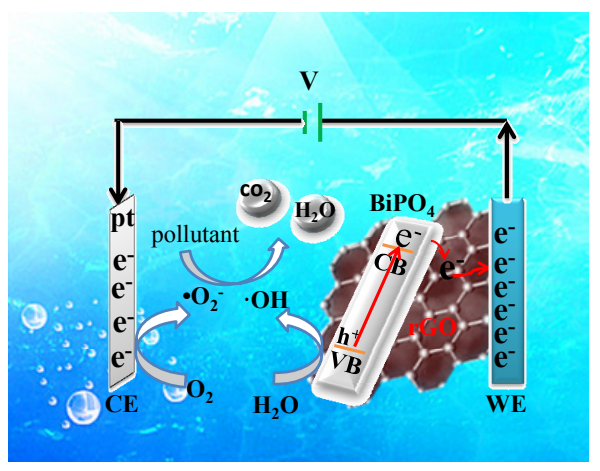

tar-zadeh, Adv. Funct. Mater, 2011, 21, 2175-2196.

[6] X. Zhang, D. Chandra, M. Kajita, H. Takahashi, L. Dong, A. Shoji, K. Saito, T. Yui, M. Yagi, Int. J. Hydrogen Energy, 2014, 39, 20736-20743.

[7] X. F. Wu, Y, Sun, H. Li, Y. J. Wang, C. X. Zhang, J.-R. Zhang, J. Z. Su, Y. W. Wang, Y. Zhang, C. Wang, M. Zhang, J. Alloys Compd., 2018, 740, 1197-1203.

[8] Z. Liu, Q. Song, M. Zhou, Z. Guo, J. Kang, H. Yan, Chem. Eng. J., 2019, 374, 554-563.

[9] D. Chen, Z. Liu, ChemSusChem, 2018, 11, 3438-3448.

[10] Y. Li, Z. Liu, J. Zhang, Z. Guo, Y. Xin, L. Zhao, J. Alloys Compd., 2019, 790, 493-501.

[11] C. S. Pan, Y. F. Zhu, Environ. Sci. Technol., 2010, 44, 5570-5574.

[12] T. K. Kim, M. N. Lee, S. H. Lee, Y. C. Park, C. K. Jung, J. H. Boo, Thin Solid Films, 2005, 475, 171-177.

[13] Y. Zhang, B. Shen, H. Huang, H. Ying, B, Fei, F. Lv, Appl. Surf. Sci., 2014, 319, 272-277.

[14] Y. F. Zhang, M. Sillanpaa, S. Obregon, G. Cobn, J. Mol. Catal. A, 2015, 402, 92-99.

[15] S. Liu, M. Y. Zhao, Z. T. He, Y. Zhong, H. Ding, D. M. Chen, Chin. J. Catal., 2019, 40, 446-457.

[16] N. C Zheng, T. Ouyang, Y. Chen, Z. Wang, D. Y. Chen, Z. Q. Liu, Catal. Sci. Technol., 2019, 9, 1357-1364.

[17] Z. Liu, E. Lei, J. Ya, Y. Xing, Appl. Surf. Sci., 2009, 255, 6415-6420.

[18] X. Zhao, H. Liu, J. Qu, Appl. Surf. Sci., 2011, 257, 4621-4624.
[19] G. Yang, D. Chen, H. Ding, J. Feng, J. Z. Zhang, Y. Zhu, S. Hamid, D. W. Bahnemann, Appl. Catal. B, 2017, 219, 611-618.

[20] Y. Li, X. Wu, W. Ho, K. Lv, Q. Li, M. Li, S. C. Lee, Chem. Eng. J., 2018 , 336, 200-210.

[21] Z. Zhou, Y. Li, K. Lv, X. Wu, Q. Li, J. Luo, Mater. Sci. Semicond. Process, 2018, 75, 334-341.

[22] K. Lv, S. Fang, L. Si, Y. Xia, W. Ho, M. Li, Appl. Surf. Sci., 2017, 391, 218-227.

[23] S. K. Mandal, K. Dutta, S. Pal, S. Mandal, A. Naskar, P. K. Pal, T. S. Bhattacharya, A. Singha, R. Saikh, S. De, D. Jana, Mater. Chem. Phys., 2019, 223, 456-465.

[24] M. Li, G. H Xu, Z. Y. Guan, Y. Wang, H. Yu, Y. Yu, Sci. Total Environ., 2019, 664, 230-239.

[25] D. Chen, J. Yang, Y. Zhu, Y. Zhang, Y. Zhu, Appl. Catal. B, 2018, 233, 202-212.

[26] D. Chen, Z. Wang, T. Ren, H. Ding, W. Yao, R. Zong, Y. Zhu, J. Phys. Chem. C, 2014, 118, 15300-15307.

[27] Z. M. Zhang, C. T. Gao, Y. X. Li, W. Han, W. Fu, Y. He, E. Xie, Nano Energy, 2016, 30, 892-899.

[28] Y. Lan, Z. Liu, Z. Guo, X. Li, L. Zhao, L. Zhan, M. Zhang, Dalton Trans., 2018, 47, 12181-12187.

[29] D. Chen, Z. Liu, Z. Guo, W. Yan, Y. Xin, J. Mater. Chem. A, 2018, 6, 20393-20401.

[30] D. Cao, Y. B. Wang, M. Qiao, X. Zhao, J. Catal., 2018, 360,240-249.

[31] C. S. Pan, Y. F. Zhu, J. Mater. Chem., 2011, 21, 4235-4241.

\section{$\mathrm{BiPO}_{4} /$ 石墨烯光电极的制备及其光电催化性能}

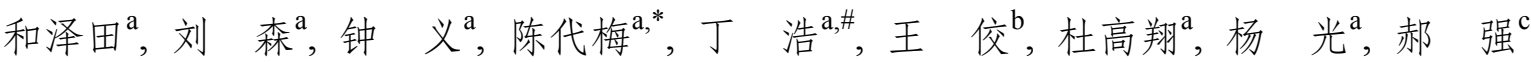 \\ a国地质大学(北京)材料科学与工程学院, 北京100083, 中国 \\ b 北京工业职业技术学院, 北京100042, 中国 \\ c 澳大利亚悉尼科技大学土木与环境工程学院, 悉尼 2007 , 澳大利亚
}

摘要: 光电催化(PEC)氧化法是一种使用半导体电极材料在光和电的共同作用下处理水中有机污染的有效方法. 在PEC工 艺中, 施加偏压不仅可以利用电催化对有机污染物进行降解, 而且在偏压作用下, 光生电子-空穴对能够得到有效的分离和 传输, 从而大大提高了机物污染物的去除速率. 尽管PEC技术已经取得了许多重要的突破, 但是能量转换效率仍然无法满 足实际应用. 因此, 开发具有优异性能, 良好稳定性和低成本的光电极材料是一项具有挑战性的研究工作.

本文采用两步电沉积法制备了 $\mathrm{BiPO}_{4}$ 纳米棒/还原氧化石墨烯/FTO复合光电极 $\left(\mathrm{BiPO}_{4} / \mathrm{rGO} / \mathrm{FTO}\right)$. 电镜结果表明, 电沉 积制得的纳米棒状磷酸铋均匀负载在石墨烯纳米片层表面. 采用甲基橙为模型体系, 考察了复合光电极的光电催化活性. 
$\mathrm{BiPO}_{4} / \mathrm{rGO} / \mathrm{FTO}$ 复合电极的光电催化降解速率是 $\mathrm{BiPO}_{4} / \mathrm{FTO}$ 光电极的 2.8 倍, 显示出优良的光电催化活性. 实验进一步研究 了工作电压和 $\mathrm{BiPO}_{4}$ 沉积时间对甲基橙光电降解性能的影响.最佳的 $\mathrm{BiPO}_{4}$ 沉积时间为 $45 \mathrm{~min}$, 最佳工作电压为 $1.2 \mathrm{~V}$. 捕获 实验和ESR 实验表明羟基自由基 $(\cdot \mathrm{OH})$ 和超氧化物自由基 $\left(\cdot \mathrm{O}_{2}^{-}\right)$是该电极的主要活性物种. $\mathrm{BiPO}_{4} / \mathrm{rGO} / \mathrm{FTO}$ 复合电极经过四 次循环实验后其降解甲基橙效率保持不变, 显示出高稳定性, 采用光电流, 交流阻抗及其苂光测试对其光催化机理进行推 测. 结果表明该复合光电极具有高PEC活性的主要原因是: 石墨烯的引入加快了 $\mathrm{BiPO}_{4}$ 的电子空穴的分离, 拓宽了石墨烯 的可见光吸收范围; 同时, 石墨烯诱导产生的 $\mathrm{BiPO}_{4}$ 混合相也进一步促进了光生电子空穴的分离, 提高了光电降解活性.

关键词: 还原氧化石墨烯; $\mathrm{BiPO}_{4}$; FTO; 电沉积; 光电催化; 甲基橙

收稿日期: 2019-09-29. 接受日期: 2019-10-09. 出版日期: 2020-02-05.

*通讯联系人. 电子信箱: chendaimei@cugb.edu.cn

通讯联系人. 电子信箱: dinghao113@126.com

基金来源：国家自然科学基金(21577132，21978276); 中央高校基本科研业务经费(2652018326，2652018298，2652018297); 北京 市教委科技计划重点项目(KZ201910853043)

本文的电子版全文由Elsevier出版社在ScienceDirect上出版(http://www.sciencedirect.com/science/journal/18722067). 